\title{
Sanctuary in Countries of Origin
}

\author{
A Transnational Perspective
}

\author{
Alexandra Délano Alonso
}

\begin{abstract}
While current interpretations of sanctuary are most often associated with practices to protect, support, and accompany migrants with precarious status in countries of destination in the Global North, debates around the concept and practice of sanctuary in countries of origin reveal different historical and contemporary understandings. This article explores questions related to sanctuary's symbolic and political power in the Mexican context, specifically examining three cases: the Mexico City government's declaration as a sanctuary city-specifically for returned migrants-in April of 2017, the work of migrant shelters along migration routes in Mexico, and the work of Otros Dreams en Acción to accompany deported and returned migrants and the establishment of Poch@ House as a sanctuary space in Mexico City.
\end{abstract}

KEYWORDS: accompaniment, deportation, hospitality, Mexico, return migration, shelters, translocal, United States

\section{Mexico as a "Sanctuary Country"}

In December 2018, a few days after a party of the Left took office in Mexico for the first time in modern history, and in the face of the recent flows of Central American migrants traveling as groups or "caravans," the newly appointed commissioner of Mexico's National Institute for Migration, Tonatiuh Guillén, declared that Mexico "will not be a country of open doors, nor a sanctuary country." This was a surprising move away from the new government's position, expressed months earlier by Olga Sánchez Cordero, appointed Minister of the Interior, who affirmed that with Andrés Manuel López Obrador's incoming administration (2018-2024), Mexico would return to its tradition as a country of asylum and refuge, as it had during moments of political and economic crises in Europe, and Central and South America in the twentieth century. The latter was considered a strong response against the former government's Plan Frontera Sur, which had effectively turned Mexico's southern border into an extension of the United States' border enforcement and deportation strategies since 2014 (see also the special section on Transit Migration in Migration and Society, 2020). This program resulted in hundreds of thousands of deportations from Mexico to Central America, in a context of wide corruption and limited institutional infrastructure that led to significant violations of migrants' rights, including abductions, extortion, trafficking, enforced disappearance, and homicides along migration routes.

The prospect of change in Mexico's discourse and strategies in the wake of a new government that promised economic development and rule of law to "make migration a voluntary choice 
rather than a forced one" (López Obrador, speech on election day, 1 July 2018) was met with significant challenges with the migrant caravans and Donald Trump's renewed emphasis on the border "emergency," including a call for an expanded border wall and stronger military presence. In early 2019, Trump added the threat of imposing tariffs on Mexican imports if López Obrador's government did not control the flow of Central Americans. At the same time, xenophobic reactions in Mexico were ignited in the context of the increased visibility of migrant flows, replicating the criminalization of migrants present in the United States, amid questions about how Mexico could offer jobs and hospitality to Central American and other migrants when it already faces such high levels of poverty, unemployment, and underemployment.

The debate quickly shifted from the Mexican government's commitment to a humanitarian approach to migration to the question of whether it could become a "safe third country" or a variation of it through the proposed Quédate en México (Remain in Mexico) program, generally referred to as Migrant Protection Protocols in the US context. As it negotiated this controversial program that would allow the United States to return asylum seekers to Mexico to await their court hearing with the Trump administration, the Mexican government promised it would also invest in development projects that would create jobs for Mexicans and Central Americans alike, and established a visa program that offered temporary legal status to around 13,000 migrants in transit or awaiting the result of an asylum claim in the United States. Contrary to this discourse, faced with increased pressures from Washington, most of the government's focus shifted toward border enforcement and controls, delivering higher numbers of detentions and deportations than the previous administration that it had so harshly criticized.

The Mexican Commissioner for Migration's remarks about Mexico not being a sanctuary country reflect the government's response to competing interests where the discourse of hospitality-and even further, the idea of sanctuary - is seen as a sign of weakness and is considered an insufficient or inadequate response to the current influx of migrants, even if it aligns to an extent with its political ideology. Guillén's remarks, intended to emphasize Mexico's ability to control its borders and develop its own independent migration policy (see the press release "Comunicado Conjunto SRE-SEGOB," 3 March 2019), brought in the concept of sanctuaryrarely used in public debates in Mexico in the context of migration-in one of its most limited and negative interpretations. The idea of sanctuary as open doors, as an amnesty, or as unlimited protection for presumed lawbreakers echoed the misinterpretations and critiques that Trump and others have expressed against sanctuary in the United States.

While in Mexico and other origin countries in the region the concept of sanctuary (santuario, in Spanish) has not had the symbolic or political power that it has in the United States or Canada in relation to migration, in fact, many practices of sanctuary have existed historically in the region, locally and transnationally, and continue today. Often referred to as practices of hospitality, shelter, or welcome, these operate mostly through networks of migrant shelters, churches, and community organizations and more recently through some policies at the municipal level and university programs (see Garrido de la Calleja and Anderson 2018). Examining such varying interpretations and practices, and what may appear as a counterintuitive application of this concept in countries with high rates of emigration, transit, or return migration, offers a generative space to rethink questions about what sanctuary is and where it sits: Who offers it and who is it for? What is its political potential? And how are its dynamics shaped by the political, economic and social connections between migrants' countries of origin and destination?

I explore these questions through various examples including the Mexico City government's declaration as a sanctuary city-specifically for returned migrants-in April 2017, the practices of migrant shelters across the country in support of migrants in transit, asylum seekers, and refugees, and the work of deported/returned migrant youth organizations. My research draws 
from semi-structured interviews, participant observation at meetings with community organizations and government offices in Mexico City, and public events held in Mexico City and New York City between 2016 and 2020. It has also been informed by conversations with the organizations, activists, scholars, and government officials mentioned here, as well as my participation as a member of the Sanctuary Working Group at The New School.

\section{Historical Origins}

Even though the term sanctuary has been reclaimed to describe actions offering solidarity, shelter, and even acts of civil disobedience in the face of deportation or other threats to migrants, refugees, and asylum seekers, it was not until the 1980s that the word acquired such a meaning in the North American context. Primarily connected to a religious setting, sanctuary has been traditionally used to describe the sacred quality of a space, such as a place of prayer or worship, a protected area for wildlife, or as a practice of offering refuge to those fleeing persecution or criminal convictions. Historically, it has generally been associated with medieval practices of churches that would allow fugitive slaves, debtors, thieves, and murderers to seek protection from corporal and capital punishment or exile (Rabben 2016). In some cases, the offer of sanctuary was contingent on either conversion to Catholicism, penance, and/or penalty (Hung 2019: 122). The practice was effectively abolished by the eighteenth century as it was considered a way to foster impunity and an infringement on sovereign jurisdiction from the perspective of the secular nation-state (Hung 2019: 122).

The contemporary use of the word sanctuary as a form of resistance to restrictive migration laws and border enforcement by local or state governments and by numerous institutions beyond the church, does not oppose the religious tradition of sanctuary, but it is not always connected to a religious congregation. Some sanctuary activists are even in direct conflict with the church. Yet, the movement generally presents itself as a continuation of such ancient practice in the sense that it appeals to a higher moral or spiritual authority beyond the nation-state, which justifies its civil disobedience, or its "divine obedience," as Anton Flores Maisonet puts it (see Lambelet 2019). The 1980s sanctuary movement, led mostly by US citizens who provided refuge for Central Americans fleeing conflict, was central in asserting that offering political sanctuary is a moral imperative, a practice of solidarity essential to our times (Bau 1985) and an act of resistance against unjust laws and against the state (Cunningham 1998).

Most of the contemporary practices of sanctuary related to migrants and refugees that have been documented are situated in the Global North. As Aimee Villarreal (2019: 48) notes, there is scant literature on sanctuary and asylum in non-Christian and non-Western societies. Generally, the historical references to the origins of sanctuary refer to medieval England or other European countries, but rarely mention examples from the Global South, where colonial histories also shaped practices of sanctuary by churches, chapels, cemeteries, convents, monasteries and hospitals, or by indigenous communities resisting assimilation (Villarreal 2019).

The case of sanctuary in colonial Spanish America, as described by Victor Uribe-Uran (2007) or Michelle McKinley (2014), is significant in terms of its endurance until the early nineteenth century and its reach. Archival research in Mexico and Perú demonstrates how widely these spaces were used by fugitives (referred to as retraídos in Spanish) of all social classes and racial groups fleeing persecution or criminal convictions, with specific regulations that limited access to certain types of criminals. Historical records also refer to similar incidents in other urban centers in Latin America, including Argentina, Chile, Colombia, Guatemala, and Panama (UribeUran 2007). Villarreal challenges this conventional history from a decolonial lens considering 
how indigenous communities in Mexico also engaged in their own forms of sanctuary through the regiones de refugio (regions of refuge) that adopted subsistence strategies and resisted processes of acculturation to survive colonialism (2019: 51).

Although the practice of church sanctuary declined after independence movements in the 1820 s and ensuing liberal reforms, most countries in the region maintained strong traditions of asylum and refuge in other forms, such as offering refuge to exiles fleeing military dictatorships in the 1960s and 1970s or civil wars in the 1980s. In addition to government policies to support refugees, during the 1980s, the US sanctuary movement also developed strong connections to churches in Mexico and created a network that formed routes for asylum seekers to the United States.

In the case of Mexico, the word sanctuary (santuario) does not have a strong association with colonial practices of sanctuary in churches in cities like Guadalajara, Mexico City, and Zacatecas (Uribe-Uran 2007), nor with current practices by migrant shelters or other institutions in support of migrant populations, which mostly use the words hospitalidad (hospitality), asilo (asylum), or refugio (refuge). The definition of sanctuary in most Spanish dictionaries, including the María Moliner Dictionary of the Use of Spanish or the Royal Academy of Spanish Dictionary (Diccionario de la Real Academia Española), only refers to its religious connotations, depicting a temple or a specific space within a church. Most associations with the term continue to be in relation to temples and sites for veneration of a saint or virgin, particularly the Virgin of Guadalupe, Mexico's patron saint. It is also used to refer to spaces for protection of animal species.

Mexican governments often lean on the narrative of Mexico as a country of "open doors" to persecuted populations-as noted in Minister of the Interior Sánchez Cordero's remarks mentioned above. This is a contested history, as Mexican governments' policies of hospitality across different periods have often been limited by political interests as well as racist and anti-Semitic views (Gleizer 2019). Nonetheless, there are a number of important examples of government and civil society-led solidarity practices around asylum-be it toward persecuted populations during the Spanish Civil War (more than 25,000 refugees), World War II (40,000 refugees), the dictatorships in Chile, Argentina, and Uruguay (12,000 refugees), or the Central American civil wars (approximately 120,000 Salvadorans were granted asylum in Mexico).

The recent inclusion of the word sanctuary in political debates in Mexico can be identified as a response to the resurgence of the US sanctuary movement in 2006 to protect migrants at risk of deportation (5-6 million of whom are Mexican) and as a reaction to Central American migrants arriving at the southern Mexican border and seeking asylum in the United States or Mexico. Some significant examples are Mexico City's declaration as a sanctuary city in 2017, the call by La 72 Hogar Refugio (The 72 migrant shelter) to declare the city of Tenosique a city of hospitality, and the use of the word sanctuary by the organization of deported/return youth Otros Dreams en Acción (ODA; Other Dreams in Action) as part of its practices and calls to action. ${ }^{1}$

Two key elements emerge from this debate that contribute to extending the discussion about the term sanctuary and its symbolic and material power beyond the context of countries of destination. First, it raises key questions about the conditions under which the practice and discourse of sanctuary carries political force, and what kind of force that is, when it is used in countries that continue to face conditions for forced migration. Some have argued that it is a contradiction in terms to apply the concept of sanctuary in countries such as El Salvador and Mexico when protection and safety cannot be guaranteed given existing conditions of criminal violence, impunity and lack of economic opportunity, and when the very actors offering sanctuary are being threatened by those same conditions. As Amparo Marroquín, professor at the University Centroamericana in El Salvador put it at the conference Transnational Sanctuary: 
Ecologies of Migrant Care and the Politics of Solidarity (The New School, New York, 12-13 April 2018).

Sanctuary is a term associated with a safe place, with a home, and in El Salvador, there is no experience of feeling safe or at home. We are a generation of a civil war and we are currently at war with the gangs. The concept of sanctuary does not take hold when out of every three Salvadorans who can find a job, two of them live outside the country. Our sanctuary is the outside world. And yet, there is an opportunity for the concept to find an anchoring in our country by bringing in what the concept has meant abroad and how it could be translated within. There is an opportunity to reinvent the term, without relying on its religious associations, and establish new linkages and solidarities building on its historical significance and the strength of the term. (Marroquín, 12 April 2018)

Similarly, Jill Anderson, co-founder of Otros Dreams en Acción in Mexico City, speaking from the Mexican context asked: "How can you talk about sanctuary in a city where you are not safe? Working in a context of scarcity, how do you argue for access for migrants, when there is already no access or infrastructure?" (Remarks at the Transnational Sanctuary conference, The New School, New York, 12 April 2018). Yet, she also proposed that this is a new context in which sanctuary may have potential, particularly given the rise in deportations that has led to new debates around access, services needed (both for deported/returned migrants and local populations) as well as new types of coalitions across civil society groups, schools, universities, and governments. The key question raised is whether and how the concept of sanctuary would be useful to articulate these linked demands through the framework of solidarity and mutuality.

Current conditions of increased migration from Central America through Mexico and increased deportations and return from the United States, have also been an opportunity to take the concept further than its limited understanding as a space of protection, and more along the lines of "expanded sanctuary," as a discourse and practice aimed at changing the structural conditions that affect both migrant and local populations (Ritchie and Morris 2017). The Mexican case, examined through these three examples, exposes the multiple ways sanctuary is being conceptualized and practiced as a result of changes in migration policies in the United States and new flows of returnees and deportees as well as migrants in transit and asylum seekers entering through Mexico's southern border. In this case, the consideration that sanctuary is informed by "the larger political, social, cultural, historical, and economic contexts in which sanctuary acts take place" (Lenard and Madokoro, this issue) needs to take into account the geopolitical dynamics that influence the discourse and practice of sanctuary, as well as who acts upon it and how, including governments, nongovernmental organizations and migrants themselves.

Second, extending the concept of sanctuary to consider deported and returned migrants who seek protections within the country where they are citizens also pushes the concept beyond its current interpretations, highlighting the fact that the conditions of exclusion and discrimination faced by migrants working and living with precarious status carry over when they return to the context of the country of origin. This shows that citizenship is not enough to guarantee equal access to opportunities and exercise of their rights, given the presence of gender, race, and other forms of discrimination

\section{CdMx as Sanctuary: A Focus on Returned Populations}

On 5 April 2017, the government of Mexico City issued a declaration of sanctuary where it affirmed its commitment to being a city of hospitality and specifically assumed a responsibility 
to guarantee the rights of all persons within its jurisdiction, particularly for Mexican migrants who are forced to return to the country, temporarily or permanently, regardless of their previous place of residence or place of origin. The city government committed to offering services, access to benefits programs, information, and assistance to both returnees and their families so they could restart their lives in Mexico City with full protection and guarantee of their rights. Specific actions derived from this declaration included modifying requirements for access to social programs, acceptance of consular IDs and repatriation forms within any government office as a valid form of identification, access to credits to support opening of businesses, free health and mental health services, and free legal services. They also offered support to obtain identification documents, unemployment insurance, training programs to enter the labor market, and accreditation processes to ensure their access to education. A call center (la Línea Migrante) offered information and a platform to report any cases of abuse or discrimination.

Mexico City is known as the most progressive city in the country, led by governments of the Left for many years, using its autonomy from the federal government to pass local legislation and implement policies regarding equal marriage and abortion rights, among other issues. In 2011, it adopted the Law of Interculturality, Assistance for Migrants and Human Mobility, which was promoted as an alternative project of service provision, inclusion, and protection for migrants. Amalia García, former Minister for Labor for Mexico City argues that the declaration of sanctuary naturally grew out of the 2011 law and the progressive history of the city (Interview, 20 August 2018). But, in her view, Mexico City officials engaged actively with cities with close affinity such as Los Angeles and Chicago, and also saw the declaration of sanctuary as a way to take a stance of resistance against the Trump administration (Interview 2018; see also Calderón Chelius 2018). Jacqueline L'Hoist Tapia, President of COPRED (The Mexico City Council to Prevent and Eliminate Discrimination), held a similar opinion but emphasized that the main impetus to adopt the term more explicitly was to address the realities of racism, classism, xenophobia, and criminalization against foreign-born persons within Mexico City (Interview, 13 August 2018).

Although in many ways the declaration of sanctuary simply reiterates much of what was already stated in the 2011 Law of Interculturality, the main difference, as highlighted by Leticia Calderón Chelius (2018), is that the 2017 declaration places an emphasis on forcibly returned populations, most of whom are Mexican citizens-even though the declaration leaves this open and does not establish citizenship as a category. In García's view, the main contribution of the declaration is that it offers a specific vision around migration that underlines a commitment to access to rights, not just a protection against abuses: "It means not deporting, but it also means guaranteeing access to rights" (Interview 2018).

The urgency to respond to the needs of citizens forcibly returning to the country where they were born became clear in the aftermath of Obama's deportation policies and Trump's threats and policies to increase deportations. In this sense, the city's particular framing of sanctuary provides an opening to discuss the concept and the practice of sanctuary not just in relation to migrants and refugees arriving at or settled in another country, but also to return migration to countries of origin. This is particularly relevant when the conditions of return are forced in contexts of violence and lack of economic opportunity, which mean that the person returning is in a similar or even worse condition than when they originally emigrated. This interpretation of sanctuary has significant potential in addressing structural conditions that limit access to rights for migrants from a transnational perspective and in a continuum that links processes of emigration, immigration, transit, and return.

As a counterpoint, Calderón Chelius (2018) argues that this declaration of sanctuary explicitly focused on returned migrants stands in contradiction with universal notions of hospitality that are at the core of the concept of sanctuary. In an attempt to make a direct statement to returned 
migrants, the declaration of sanctuary could be seen as exclusive by focusing on a particular group instead of leaving it open to anyone who arrives in need of protection, regardless of their nationality or the process of migration that led to their presence in the city. Yet, the municipal government argues that those other groups were already protected by existing legislation and programs and this declaration just added another group. Moreover, Calderón Chelius criticizes the fact that such a declaration may depoliticize the larger debate about the fact that Mexican citizens returning to their own country should not need to be protected by a declaration of sanctuary. In her view, it also allows for the continuing invisibilization of historical and current racism and discrimination against migrants in Mexico, which challenges patriotic narratives of Mexico as a country that has welcomed exiled populations. From this perspective, she raises similar questions to the ones posed by Jill Anderson and Amparo Marroquín: "How to focus on creating conditions of equality when the societies that migrants are arriving to/returning to are in themselves profoundly unequal, with extremes of poverty and conditions of violence similar to those that migrants are fleeing? How to build empathy in the society of reception when new members arrive that are demanding similar support systems to the ones needed by local populations?" (Calderón Chelius 2018). A provocative and very practical response to these questions has been built from the ground up, from the perspective of those working with migrant populations within the network of shelters that has grown significantly in recent years throughout the country, with a focus not so much on changing policies, but rather transforming processes and communities to address conditions that affect everyone-migrants and locals-equally. While the concept of sanctuary is not directly employed, practices of accompaniment and hospitality within migrant shelters and their advocacy beyond these spaces reflect this vision and provide an alternative as well as a form of resistance to government actions and inactions (on both sides of the border), as discussed in the next section.

In the context of the migrant caravans, since 2018 other cities have issued declarations of solidarity and strengthened their legal framework in support of migrant populations, such as Oaxaca, where the constitutional reform passed in July 2019 emphasizes that it will protect the rights of all migrants, including Mexican nationals and foreign-born. Although it does not explicitly mention returnees or deportees nor the concept of sanctuary, many local officials and the media framed this constitutional change as a declaration of sanctuary (see, for example, Flores 2019 and Grupo Parlamentario Senado MORENA 2019).

In Mexico City, the election of a new mayor in 2018 led to administrative changes including a restructuring of programs to support national and foreign-born migrant populations. Despite the former declaration of sanctuary, the language of sanctuary city has been abandoned, and in 2019 existing programs were replaced by the "City of Hospitality and Human Mobility Program." When I asked one of the government officials presenting the new program to a group of civil society organizations why the language of sanctuary was no longer used, she expressed that "it was a term used by the previous administration and we're not sure if we're going to continue with it: surely, something even better will emerge" (meeting with the Instituto de Atención a Poblaciones Prioritarias: Coordinación de Migrantes, Mexico City, 27 May 2019); a clear example of how the term is not widely seen as effective from a political perspective in the Mexican context.

\section{A Network of Migrant Shelters within and beyond Sanctuary}

On 27 February 2018, in the context of the Viacrucis Migrante activities, the 72 Migrant Shelter (La 72 Hogar Refugio) issued a call to declare the city of Tenosique, Tabasco (where the shelter is located), a "city of hospitality" ("Viacrucis Migrante 2018," email, 18 June 2018). Their mes- 
sage explicitly called for a citizen declaration (not a government declaration) of the city as a city of hospitality and protection that supports and promotes the integration of people undergoing forced mobility. It emphasized the importance of strengthening social structures from within origin countries to create humanitarian paths that promote solidarity and holistic support. Beyond a conventional vision of the work of shelters primarily as a temporary form of assistance, La 72 frames its mission and goals as "responsible hospitality with dignity," with a vision toward "integration as a process of liberation and mutual recognition" (Statement on World Refugee Day, email, 18 June 2018). Thus, in addition to providing food and shelter-and more recently, legal support and accompaniment for asylum cases-its actions involve taking migrants beyond the shelter into the community to engage both locals and migrants in actions and conversations around structural conditions that affect them all equally, including poverty, violence, discrimination, exclusion, and access to jobs. A noteworthy example of this approach is the establishment of the agroecological farm "Laudato Si': Trabajo, Tierra, Techo," a project focused on creating sustainable food systems for the shelter as well as opportunities for people staying there to work in dignified conditions (Gil Everaert, forthcoming). The project is part of La 72's focus on changing structural conditions that can improve the situation of people in mobility as well as their relationship with the local community. Some of the locals provided assistance and support to identify what could be planted in the lot and shared traditional farming practices; others were hired to build some of the structures in the farm. The shelter has also held celebrations there focusing on local gastronomy and nutrition that seek to strengthen ties between the community and the migrants (Gil Everaert, forthcoming).

Fray Tomás González, founder of the shelter, defines La 72 as "liberated territory" where new political and economic identities are built: "from the beginning we've valued autonomy, revolution, a new social, political, and economic identity independent of the church. We're in conflict with everything that has to do with power: with the church, the state, anything, with all authorities, especially security forces, the military, the federal police, state police, the marines-we've had problems with all of them" (Interview, Ecologies of Migrant Care, 13 November 2016). This vision, grounded in liberation theology, sees the power in community and grassroots movements and reflects a similar position as those who advocate for radical, abolitionist networks of sanctuary communities beyond institutional frameworks in the US context and elsewhere (see Maira 2019; Paik et al. 2019).

La 72 is part of a network of 60 to 100 migrant shelters established throughout the country since the mid-1990s that has grown since 2005 in the context of increased transit migration and stricter enforcement on both the US and Mexican borders, as well as the violence in Mexico resulting from the "War on Drug Cartels" begun in 2006. Their work generally focuses on providing support throughout migrant journeys, including a temporary place to live, food, medical assistance, legal representation, and advocacy around migrants' rights. Many of these shelters are led by religious leaders and are organized around theological principles of hospitality even though they also challenge and move beyond them (Brigden and Naatus 2014). Many of these religious leaders, such as Father Pedro Pantoja Arreola, have emphasized that migrant shelters provide more than food, a place to sleep and protection against abductions and extortion; they are "a space for building political consciousness and transforming individuals, helping migrants transition from victims into protagonists of their own liberation" (Ruiz Parra 2012: 141).

Similarly, Norma Ramírez, one of the founders of Las Patronas, a group of women in the town of La Patrona, Veracruz, describes their practice of cooking, packing, and delivering food to migrants passing by their town on the freight train infamously called La Bestia (The Beast), as a practice of "providing nourishment but also accompaniment." Beyond an understanding of this practice as assistance from citizens to migrants, she articulates this as "a horizontal process 
that makes all participants equal" (Comments after screening of Las Patronas documentary, The New School, 3 May 2018). According to her view, the process of accompaniment transforms the migrants, but also transforms the women who provide the food and the rest of the community, from gender roles to social consciousness and education around the structural violence present throughout the migration process: "I, like these migrants, also dream. They dream about getting to the United States, I dream about changing the environment of my community" (Interview, Ecologies of Migrant Care, 13 August 2017).

A similar framing of sanctuary as mutual transformation is used by groups such as the New Sanctuary Coalition in New York, although they do not always have a direct or consistent connection to this or other groups in Mexico. This type of framing of sanctuary as accompaniment, mutual liberation, and transformative politics is clearly expressed by Rev. Juan Carlos Ruiz in the New York City context, where he argues that "sanctuary is not just as an intellectual exercise or a religious creed; it's not about people of faith but people who are practicing justice; not about what we believe in but what we practice as human beings. The transformative power of sanctuary is unleashed when someone comes into sanctuary. The power of relationships is reconfigured, restructured; it changes who we are as people" (Transnational Sanctuary, 12 April 2018).

Reflecting on similar processes from the perspective of Honduras, Padre Melo, a religious figure widely known as a human rights activist, argues that the work that sanctuary calls for is to break existing paradigms at the center of cycles of discrimination and insecurity from the perspective of those suffering, and to generate another way of living through relationships of horizontality and equality (Transnational Sanctuary, 12 April 2018). From his perspective, even though many existing practices in Central America and Mexico are not referred to as sanctuary, as conceived in the US context, in fact, they are generating new responses "to defend that which is sacred, which is human life." In his view, sanctuary has potential because it signals a place of encounter and solidarity with lives being threatened, which is how the work of most migrant shelters actually operates, even if the word sanctuary is generally not used.

Most of these practices of radical solidarity challenge the government and its institutions but also the church itself. John Fife, in particular, notes that while the sanctuary movement of the 1980s in the United States was led mostly by faith-based institutions, nowadays it has become a more layered movement predominantly led by cities, counties, states, universities, and colleges. At the same time, in his view, the current moment has revived existing transnational networks that emerged during the 1980s sanctuary movement, which are now leading to new practices of justice and accompaniment. Building on the historic weight of the sanctuary movement but moving toward new transformative aims, these practices can address both urgent needs and structural realities for migrants in transit, refugees, and those facing deportation and family separation across borders (Remarks at Transnational Sanctuary workshop, 12 April 2018).

Networks of shelters and activists are challenging border enforcement mechanisms by establishing spaces of protection, resisting the implementation of government policies, and exposing violations of rights. At the same time, similarly to many sanctuary activists in the United States and other countries, their practices show an expansive interpretation of sanctuary or hospitality beyond the confines of a temporary space for protection and beyond the state. Theirs is a vision focused on transformative politics that addresses structural conditions of exclusion and do not merely focus on assistance or the need for policy change.

\section{Sanctuary Post-deportation}

Finally, moving beyond the processes of transit, immigration, and asylum that have often been associated with conventional notions of sanctuary, a number of migrant-led organizations have 
developed similar principles to those of the sanctuary movement in the United States to address the reality of post-deportation in Mexico, signaling the need for broader processes to address the structural realities of exclusion beyond what is established even within Mexico City's declaration as a sanctuary city.

The aftermath of US policies of deportation has led to the return of more than three million people to Mexico and Central America (and other regions) who are met with significant obstacles upon arrival after building lives abroad for years or decades. They receive little (if any) institutional support, and social stigmas create barriers and limit their access to basic services, educational, health, housing and employment opportunities in the country where they are recognized as citizens. In Mexico, deported and returned youth have organized a network of support to advocate for their rights and to create a community space for returnees, including the community organization Otros Dreams en Acción (ODA) and their practices of "holistic accompaniment" (acompañamiento integral). This consists of support for deportees/returnees recently arrived at airports or bus stations, including immediate needs (i.e. clothes, hygiene kits, food), as well as resources with a medium- and long-term focus on legal aid, employment, housing, mental and emotional health, and community spaces. These practices stand in stark contrast to government policies that focus merely on basic assistance at the moment of arrival.

Otros Dreams en Acción articulates a transnational vision of rights that addresses the conditions of violence and exclusion throughout the migration process (Anderson 2019) and proposes everyday practices of mutual aid, solidarity, and advocacy strategies that focus on the economic, social, and political inequalities that affect the returnees as well as their communities at large.

As part of this holistic focus and the goals of making returnees/deportees visible and building community, ODA established Poch@ House in 2018. A big bright room on the third floor of an old building in downtown Mexico, with a mural and decorations that allude to experiences of deportation, family separation, and multilingual/multinational identities, Poch@ House is a community cultural space that offers workshops, trainings, English classes taught by deportees/ returnees, among other activities. Some of these are focused mainly on returned migrants, others on migrant populations more broadly, and others are geared toward the local community as a whole.

Using a strategy similar to the Dreamers' movement challenge to the term "undocumented," which youth in the United States embraced and made part of their struggle (adding to it the words "unafraid" and "unapologetic"), by naming its space "Poch@ House," ODA appropriated the term pocho. This word, meaning "rotten fruit," has negative connotations and has often been used by Mexicans in Mexico as a derogatory term against Mexicans who "become Americanized" through the process of migration. The gender-neutral symbol at the end also expresses the organization's intersectional approach. Maggie Loredo and Jill Anderson, co-founders of ODA, refer to Poch@ House as a sanctuary, a safe space, a space of healing and care that recognizes their communities' multiple identities, languages, and struggles. On its website, ${ }^{2}$ the organization describes its three main areas of focus as "sanctuary," "support," and "culture." Sanctuary is described mainly as a space for community and belonging: "Here we can speak Spanglish, be ourselves in all our diversity, find those who have got our backs, and create a cross-border community out of this crisis." But as Maggie Loredo puts it, the concept of sanctuary does not fully capture their vision and practice: "It's a place that is not only a safe space or a sanctuary, or however you want to call it. It's a space that gives us the freedom to be who we are, to speak how we want ... it's also a place where we're not helping people; we're accompanying people" (Interview, Ecologies of Migrant Care, 13 April 2018).

One of the most interesting aspects of this space is that due to the binational, bicultural and bilingual characteristics of the population of returned and deported migrants, the understand- 
ing of the concept of sanctuary and its use in the Mexican context seems much more natural. Many of thevocer@s (community leaders) of the organization have been activists in the United States as part of the Dreamers movement and other struggles or are familiar with them, and therefore understand the role of language and concepts such as sanctuary in transforming narratives and debates. They also assert transnational linkages between the oppressive conditions they have faced in both countries and the struggle against them through sanctuary activism and its connection to other movements (see Loredo interview, Ecologies of Migrant Care, 13 April 2018).

In this sense, although nascent and small relative to the migrant shelters and other organizations that have received more attention, the work being developed from ODA, with a focus on "translocality as an aspiration" (as Anderson describes it), offers a different way to envision the role of the concept and practice of sanctuary beyond territorial borders, beyond its association with faith-based institutions, but also as a term that frames the struggle of migrant populations in relation to two (or more) countries (and more specifically, cities or towns) where their identities, relationships and livelihoods are located. Other examples of such transnational conversations among migrant solidarity activists in the United States, Europe, Canada, and Australia also identify a shared intersectional, transnational sanctuary framework (Maira 2019).

The recognition of the demands of returned and deported migrants faces the challenge of building political support and sustained coalitions with organizations focusing on other aspects of migrants' rights, both within Mexico and transnationally. Yet, their framing of the struggle as one focused on "local well-being that crosses borders," as described in their 2019 artistic intervention "Florecer Aquí y Allá" (Flourish here and there), has the potential of building solidarity from a perspective of mutuality and "linked fate," as Janaé Bonsu, National Policy Chair of Black Youth Project 100, an organization of Black youth activists founded in 2013 and dedicated to "justice and freedom of all Black people," puts it (Ritchie and Morris 2017). Their perspective resonates with the calls for expanded sanctuary in the United States as a discourse and practice aimed at changing the conditions that affect both local and migrant populations, with the added component of framing this as a translocal struggle.

\section{Conclusions}

The analysis of the concept and practice of sanctuary from the perspective of Mexico reveals some of the tensions in the use of this framing. Its translation into contexts where economic and political conditions appear incompatible with the moral commitment to guarantee the protections and safety that the concept of sanctuary implies, offers new possibilities to examine and question different interpretations and practices of sanctuary beyond the politics and territory of countries of destination.

The case of the Mexico City government exemplifies the influence of the US sanctuary city movement in local Mexican officials' use of the language of sanctuary to position themselves politically against or for specific migration policies, in this case giving particular emphasis to returned/deported populations. Its focus is mostly on assistance, although its offer of a wide range of services reflects a more holistic perspective than municipal government declarations of sanctuary city limited to protection of information or non-cooperation with federal authorities. This case raises a significant question of whether and why sanctuary-in its contemporary interpretation related to populations with precarious migration status-is necessary for citizens returning to their own country, and what sanctuary means in this particular case given that there is no threat of deportation or exclusion specifically based on their citizenship, but rather a set 
of structural conditions that lead to discrimination and marginalization. This is precisely what activists focusing on "expanded sanctuary" or "freedom cities" argue for in the US context, in the sense that citizenship status is not enough to guarantee conditions of equality and justice for marginalized communities, particularly people of color. From this perspective, Mexico City's declaration of sanctuary is a powerful move toward the recognition of the conditions of exclusion faced by migrant populations throughout the migration process and the responsibility of origin countries to address them, including when they return to the country where they are citizens.

The work of migrant shelters along migration routes throughout Mexico exemplifies a more dynamic, self-critical, expansive, and transformative practice of sanctuary that is not just focused on providing assistance and shelter, but rather on building new relationships and forms of community and eventually an alternative system that implicates both migrants and locals. Similar to many sanctuary activists of the 1980s and the organizations leading the movement today in the United States, this is a vision that articulates practices of solidarity not just as a reaction to unjust laws and a form of civil disobedience expressed nationally and transnationally, but also as proactive, prefigurative politics that seek to rebuild the social fabric from a perspective of horizontality and equality of all (Coutin 1993). As Padre Melo puts it: "this means rethinking the concept of sanctuary not just as physical space or as refuge, but as a dynamic, mystical and spiritual force that puts human dignity at the center, that focuses on processes rather than events" (Transnational Sanctuary, 12 April 2018).

Although Padre Melo and others see the value in using the term, the historical associations with the term sanctuary, and the use of the word in Spanish mostly in its religious connotations, so far have limited the debate around the political potential or the limitations of the term in this context. A question is whether the move toward using this framework more broadly is necessary or worthwhile in the Mexican case. On the one hand, it could strengthen sanctuary movements' ability to articulate their demands and provide protections for migrants throughout migration processes by enhancing transnational connections across the region in a more clear and intentional way. But this could also generate more backlash given some of the negative associations with the term both in relation to its problematic history and its current characterization by the right as a practice of harboring criminals that puts communities in danger. In this sense, Aimee Villarreal's work is an important reminder of the need “for a radical reorientation of sanctuary's given terms and historical trajectories" (2019: 44), which demonstrate its potential in relation to forms of resistance that pre-date colonial times and connect this movement to other transformative projects in the present, particularly those of indigenous groups. Focusing on practices in the Global South can be an opportunity for such a reorientation.

The resonance of the discourse and practice of sanctuary among returned and deported populations that have experienced conditions of exclusion, as well as the possibilities of political organizing around the term, also open new ways of defining the term and using it both in relation to community practices and to political resistance. It also places the focus on a definition of sanctuary that is determined by and for migrants, in this case deportees and returnees, who challenge the binary of citizen/non-citizen, guest/host against the conventional and problematic structure of sanctuary or hospitality offered by a host (usually a citizen) and received by a migrant (see Berg and Fiddian-Qasmiyeh 2018).

Focusing on sanctuary from the perspective of Mexico as a country of origin/transit/return, and more recently also a destination country for asylum seekers and refugees, underscores the geopolitical dynamics that shape sanctuary discourses and practices. In this case, Mexican government offices (at the national and local level), as well as activists and organizations, are responding in different ways to how sanctuary is being defined and practiced in the United States. At the same time, they are adapting to changing migration flows in the northern and 
southern borders and to political and economic conditions present in Mexico that reveal different tensions and possibilities for the use and practice of sanctuary in relation to migrant and non-migrant populations. Their actions, whether or not framed directly as sanctuary, demonstrate the potential for offering a counternarrative to unjust economic and political systems and conceptualizing and practicing transformative solidarity across borders.

\section{ACKNOWLEDGMENTS}

For their comments and suggestions, I thank the organizers and participants in the Stakes of Sanctuary workshop, McGill University, Montreal, 7-8 March 2019. I am particularly grateful to Shannon McSheffrey for her feedback and the references to sanctuary in Spain and its Latin American colonies, and to Laura Madokoro for her comments on a draft of this paper. I also thank all members of The New School Sanctuary Working Group as well as the participants in the Expanded Sanctuary and Transnational Sanctuary workshops held at The New School in 2018, including many of the activists and organizers mentioned here, all of whom have significantly influenced my thinking around sanctuary and led me to many of the references cited here. I am also grateful to Marianna Poyares and Tatiana Llaguno for their research assistance. Finally, to the editors of Migration and Society and the anonymous reviewers, my gratitude for their helpful feedback.

ALEXANDRA DÉlANO ALONSO is Associate Professor and Chair of Global Studies and the current holder of the Eugene M. Lang Professorship for Excellence in Teaching and Mentoring. Her research focuses on diaspora policies, transnationalism, sanctuary, and the politics of memory in relation to borders, violence and migration across the Central America-Mexico-U.S. corridor.Her publications include From Here and There: Diaspora Policies, Integration and Social Rights Beyond Borders (Oxford University Press, 2018). She is a faculty fellow at the Zolberg Institute on Migration and Mobility and a member of The New School's Sanctuary Working Group. E-mail: delanoa@newschool.edu

\section{NOTES}

1. The name of the organization alludes to but also departs from the term "Dreamers," commonly used in reference to youth eligible for the Development, Relief, and Education for Alien Minors Act (also known as the "DREAM Act"), a US legislative proposal that would regularize the status of individuals who were younger than 18 years of age on the initial date of US entry, among other conditions (S.87, Dream Act of 2019, 116th Congress [2019-2020]).

2. Otros Dreams en Acción, “About Us." http://www.odamexico.org/ (accessed 31 January 2021).

\section{REFERENCES}

Anderson, Jill. 2018. Remarks at the Transnational Sanctuary: Ecologies of Migrant Care and the Politics of Solidarity Conference, 12-13 April, The New School, New York.

Anderson, Jill. 2019. “The Deportability Continuum as Activist Research.” Cultural Dynamics 31 (1-2): 125-139. 
Bau, Ignatius. 1985. This Ground Is Holy: Church Sanctuary and Central American Refugees. Mahwah, NJ: Paulist Press.

Berg, Mette Louise, and Elena Fiddian-Qasmiyeh. 2018. "Introduction to the Issue: Encountering Hospitality and Hostility." Migration and Society 1 (1): 1-6.

Brigden, Noelle Kateri, and Mary Kate Naatus. 2014. "Padre José Alejandro Solalinde Guerra’s Understanding of Ultimate Reality and Meaning", Ultimate Reality and Meaning 33 (3-4): 235-254.

Calderón Chelius, Leticia. 2018. "La hospitalidad imaginada o cómo podemos construir una ciudad hospitalaria sin exaltar los mitos que nos dieron patria," [The imagined hospitality or how we can build a hospitable city without exalting the myths that gave us a homeland]. Sin Fronteras.

Coutin, Susan B. 1993. The Culture of Protest: Religious Activism and the U.S. Sanctuary Movement. Boulder, CO: Westview Press.

Cunningham, Hilary. 1998. "Sanctuary and Sovereignty: Church and State Along the U.S.-Mexico Border." Journal of Church and State 40 (2): 371-386.

Ecologies of Migrant Care, Hemispheric Institute of Performance and Politics at New York University. https://migration.hemi.press/.

Flores, Lizbeth. 2019. 'Oaxaca se erige como 'santuario' para migrantes." [Oaxaca stands as a 'sanctuary' for migrants], El Universal, 10 July. https://www.eluniversal.com.mx/estados/oaxaca-se-erigecomo-santuario-para-migrantes.

Garrido de la Calleja, Carlos A., and Jill Anderson (coords.) 2018. ¿Santuarios educativos en México? Proyectos y propuestas ante la criminalización de jóvenes dreamers retornados y deportados [Educational sanctuaries in Mexico? Projects and proposals in the context of the criminalization of young returned and deported Dreamers.] Xalapa, México: Universidad Veracruzana.

Gil Everaert, Isabel. Forthcoming. "Dignificar la espera. La granja agroecológica Laudato Si: Techo, Trabajo, Tierra y la inclusión integral de las personas refugiadas en Tabasco, México." [Dignify the wait. The Laudato Si agroecological farm: Roof, Work, Land and the integral inclusion of refugees in Tabasco, Mexico] In Hacia otras economías para dignificar las condiciones de vida de las y los migrantes en México, Colombia, Argentina y Uruguay, ed. L. Oulhaj. Mexico City, Mexico: Universidad Iberoamericana.

Gleizer, Daniela. 2019. "Dos exilios, una memoria y un olvido." [Two exiles, a memory and a forgetfulness]. Letras Libres (247): 28-30.

Grupo Parlamentario Senado MORENA. 2019. "Al convertir a Oaxaca en santuario para personas migrantes, el Congreso Estatal es ejemplo a seguir: Salomón Jara," [By turning Oaxaca into a sanctuary for migrants, the State Congress is an example to follow: Salomón Jara]. Boletín, 10 July. https://morena.senado.gob.mx/2019/07/10/al-convertir-a-oaxaca-en-santuario-para-personasmigrantes-el-congreso-estatal-es-ejemplo-a-seguir-salomon-jara/.

Hung, Carla. 2019. "Sanctuary Squats: The Political Contestations of Piazza Indipendenza Refugee Occupiers." Radical History Review (135): 119-137.

Lambelet, Kyle B. T. 2019. "Sanctuary in a Small Southern City: An Interview with Anton FloresMaisonet." Radical History Review (135): 160-169.

Lenard, Patti Tamara, and Laura Madokoro. 2021. “The Stakes of Sanctuary," this issue.

López Obrador, Andrés Manuel, 2018. Palabras AMLO con motivo del triunfo electoral del 1 de julio [Remarks by AMLO on the occasion of the electoral win on July 1, 2018] https://lopezobrador.org .mx/2018/07/02/palabras-amlo-con-motivo-del-triunfo-electoral-del-1-de-julio/

Maira, Sunaina. 2019. "Freedom to Move, Freedom to Stay, Freedom to Return: A Transnational Roundtable on Sanctuary Activism." Radical History Review (135): 138-159.

Marroquin, Amparo. 2018. Remarks at the Transnational Sanctuary: Ecologies of Migrant Care and the Politics of Solidarity Conference, 12-13 April, The New School, New York.

McKinley, Michelle A. 2014. "Standing on Shaky Ground: Criminal Jurisdiction and Ecclesiastical Immunity in Seventeenth-Century Lima, 1600-1700.” UC Irvine Law Review (141): 141-174.

Paik, A. Naomi, Jason Ruiz, and Rebecca M. Schreiber. "Sanctuary's Radical Networks." Radical History Review (135): 1-13. 
Rabben, Linda. 2016. Sanctuary and Asylum: A Social and Political History. Seattle: University of Washington Press.

Ritchie, Andrea J., and Monique W. Morris. 2017. Centering Black Women, Girls, Gender Nonconforming People and Fem(me)s in Campaigns for Expanded Sanctuary and Freedom Cities. Chicago: National Black Women's Justice Institute.

Ruiz, Juan Carlos. 2018. Remarks at the Transnational Sanctuary: Ecologies of Migrant Care and the Politics of Solidarity Conference, 12-13 April, The New School, New York.

Ruiz Parra, Emiliano. 2012. Ovejas Negras: Rebeldes de la iglesia mexicana del siglo XXI. [Black Sheep: Rebels of the Mexican Church of the XXI century]. México City: Océano.

Secretaria de Relaciones Exteriores. 2019. "La política migratoria de México es soberana y busca preservar los derechos de los migrantes" [Mexico's migration policy is sovereign and seeks to preserve the rights of migrants] Comunicado conjunto SRE-SEGOB. https://www.gob.mx/sre/prensa/ la-politica-migratoria-de-mexico-es-soberana-y-busca-preservar-los-derechos-de-los-migrantes Uribe-Uran, Victor M. 2007. "Iglesia me Llamo': Church Asylum and the Law in Spain and Colonial Spanish America." Comparative Studies in Society and History 49 (2): 446-472.

US $116^{\text {th }}$ Congress. 2019. S.874. Dream Act of 2019. https://www.congress.gov/bill/116th-congress/ senate-bill/ 874

Villarreal, Aimee. 2019. "Sanctuaryscapes in the North American Southwest." Radical History Review (135): 43-70. 